\title{
PROFESSIONAL PREPARATION OF THE TEACHER FOR THE NEW UKRAINIAN PRIMARY SCHOOL
}

\author{
ANNA VOITOVYCH
}

\begin{abstract}
The article covers to the actual problems of vocational training of the future teacher of the primary school in the context of reforming the education system in Ukraine. Considerable attention is paid to the socio-cultural component in the pedagogical process of a higher educational institution, as well as the issues of standardization of education. The author emphasizes that dynamic social processes, the phenomenon of globalization, the need for formation of a civil society, fostering of national consciousness and identity determine the interest of the public in the described issues, first of all for teaching. The theoretical aspects of teacher training for creation of socio-cultural educational environment of the primary school, the realization of possibilities of socio-cultural mobility and others are substantiated. It is proved that socio-cultural mobility of a teacher, which is closely connected with the process of professionalization, implies active activity according to the adapting and accepting the values of a socio-cultural environment. It was emphasized on the need to prepare future specialists of primary education for the purposive sociocultural upbringing of children.
\end{abstract}

Keywords: teacher training, standardization of education, socio-cultural mobility, New Ukrainian School, inclusive education, Higher Educational Institution.

\section{INTRODUCTION}

In modern conditions, the reformation of the domestic system is implemented actively, its transition to a qualitatively higher level of educational services. Education as a "special socio-cultural phenomenon" is one of the important factors of innovative processes in the Ukrainian educational system because it performs such functions as: reproduction of cultural patterns and standards of life in educational structures; formation of social and spiritual life of a person; the acceleration of cultural changes and transformation in public life and the individual [12, p. 105].

According to V. Kremen, in the contemporary conditions it is important to consider education as "a social institution and as a pedagogical system that covers the technology of educational activity (methods, teaching, content, forms and methods of organizing the educational process)" [4, p. 319-320]. Actually, in this context, the work of teacher-innovators, theorists, and practitioners according to the modernization of the pedagogical science is valuable. At the same time, "educational reform is not limited to the pedagogical innovations, natural in any circumstances. It sees the main goal in the radical transformation of the educational system especially as a social institution" [4, p. 319-320]. The scientist 
emphasizes that our school is "an institution first of all of culture, which solves the task of preparing the child not only for professional but also for social life" [4, p. 322].

The Law of Ukraine "On Education" (2017) emphasizes that the goal of modern education is "the comprehensive development of a person, the formation of values which are necessary for a successful self-realization of competences, the education of responsible citizens who are capable of conscious social choice and the direction of their activities in favor of others people and society, enriching on this basis intellectual, economic, creative and cultural potential of the Ukrainian people, raising the educational level of citizens in order to ensure a sustainable development of Ukraine and its European choice" [6].

Based on the provisions and leading directions of the implementation of the Laws of Ukraine "On Higher Education" (2015), “On Education” (2017), the Concept of General Secondary Education (2001), the National Doctrine of the Development of Education in Ukraine in the XXI century (2002), National Strategy for the Development of Education of Ukraine for the period up to 2021 (2013), State Standards for General Elementary Education (2011), Concept "New School. The Space of Educational Opportunities" (2016) and others, we note that the modern educational system requires highly qualified specialists capable of competitive pedagogical activity in an innovative society, self-education, self-development and professional self-improvement and capable of successful implementing of educational standards, advanced pedagogical technologies.

"Pedagogical consciousness of the teacher, the Polish scientists note, should be considered from the point of view of a new situation, new needs and tasks" [7, p. 19], it means taking into account social requirements for the personal and professional formation of the future teacher.

The problem of the professional training of the future teacher is highlighted in the scientific works of foreign and Ukrainian scholars (Yu. Babanskyy, H. Vasianovych, S. Goncharenko, R. Gurevich, I. Zyazyun, V. Kremen, V. Kuz, Z. Markocki, P. Mazur, O. Marynovska, N. Machynska, N. Morse, T. Piątek, A. Sajdak, R. Skulskyy, G. Filipchuk, etc.). Different aspects of the training of future primary school teachers are reflected in the doctoral dissertations of such scientists: N. Bibik, V. Bondar, O. Budnyk, O. Kucheriaviy, S. Martynenko, I. Palshkova, O. Savchenko, O. Hyzhna, L. Khomych, O. Fediy, O. Yaroshynska and others. However, the problem of the professional training of a future specialist in primary education in the socio-cultural dimension is considered insufficiently highlighted.

The goal of the article is to substantiate the theoretical aspects of the professional training of future teachers in the socio-cultural dimension of the New Ukrainian Primary School.

\section{ANALYSIS AND DiscUSSION}

In modern philosophical and pedagogical science, the socio-cultural dimension of education is considered as the process of optimal inclusion of personality in the world of science and culture within the general spiritual development of society. Thereafter, the training of the future teacher of primary school is defined as the social and value process of the implementation of the subject and subjective relations between the teacher and the student, (teacher and student) in the socio-cultural environment. Thus, "the creation of a modern system of pedagogical education should be based on national and educational traditions, their preservation and multiplication, and the same time, taking into account the best achievements in pedagogical education of other countries" [7, p. 19]. In our study, we consider the socio-cultural aspects of teacher training. Actually readiness to form a "holistic, fully developed personality of a student capable of critical thinking", and at the same time "a patriot with an active position who acts according to moral and ethical principles and able to make responsible decisions", as it is stated in the Concept of the New Ukrainian School [8, p. 6].

The system of professional training of primary school teachers is an integral complex of interconnected structural elements: goals, tasks, content of education, methods and means of teaching, forms of organization of pedagogical process, results, etc. The specificity of the preparation of the primary school teacher is due to the fact that he works with specific children of the class, conducts a multidisciplinary teaching, but the task of the professional activity is not only personally, but also 
socially conditioned - preparing students for mastering the content of education in the primary and secondary schools, as well as - for active participation in public life, conscious discovery of a civil position. In order to enable these students to join different spheres of life in the future (develop science, art, produce products, work in the field of international relations, expand social experience), the primary school teacher must develop in them the so-called foundation of a human personality, give a solid foundation for mastering the basics of sciences.

\subsection{Preparation of the Future Teacher in the Conditions of Standardization of PRimary Education}

The reformation of modern education in Ukraine is inseparable from the issue of its standardization. This is an effective direction, first of all, of the regulatory and legal regulation of the education system. And it is very important. "Through the introduction of higher education standards, school plan, curriculum, textbook, manuals on a particular discipline receive a common core, a reference point and a criterion for assessing their quality. Standardization of higher education integrates the purpose, tasks, values, principles, forms, content and methods of educational activity" [5, p. 91]. The standard of higher education is an important official document, a certain academic norm, a "large-scale socio-cultural project that covers all levels of education" [5, p. 94].

The urgent problem of developing standards for general secondary and higher education is to take into account the best world educational experience, as well as to ensure a close connection between the theory and practice. Nowadays, Ukraine has virtually no standards for the training primary school teachers, and each pedagogical institute or university, using its autonomy, independently defines the content of vocational education.

An important problem in teacher training is its detachment from the educational practice in school. So, starting from 2018 school year, Ukraine has proposed the transition of all primary schools to work through the integrated training methodology. At the same time, pedagogical universities are not yet sufficiently adapted to prepare an innovative teacher who is capable of implementing the outlined training educational, and developmental tasks. Actually, functionality is considered to be one of the main requirements for teacher training. As Z. Markontski notes, this characteristic, besides the study, also involves mastering the values and skills to use them in practice, in particular in innovation [7, p.18].

In educational practice, a revised term is considered to be a revision of educational standards at least once every 10 years in order to evaluate their effectiveness in practice in a real way. Ukrainian realities are somewhat different - educational standards change very often, which is primarily due to the political crisis in the country. This leads to a change in government structures, and of course a new educational policy. Separate innovations have so-called accelerated character, therefore, educational institutions, pedagogical workers, material equipment of the pedagogical process are not ready for these changes. It has a certain impact on the quality of the provision of educational services. Absolutely, it also applies to the problems in the content of the primary school teacher training, and there are also difficulties in terms of contradiction of new standards (or their lack) of the real resource opportunities of higher education.

New educational standards of training teacher for work at the New Ukrainian Elementary School require careful testing and consideration of the regional features of educational institutions. The effective way is the correspondence of scientific and technical activities "as a direct function of regional educational systems ... key properties such as: polysystem, creativity, singularity, discreteness, uncertainty, co-operativity, synergy, integrability, universality and globality" [11, p. 108].

According to A. Shevchuk, modern standardization of education should take into account the "territorial specificity of the development of education", and it means "a more specific approach to the implementation of innovations with anchorage in certain regions". Therefore, in the opinion of the scientist, "it is worthwhile, on an experimental basis, to provide additional autonomy to local authorities (the Department of Education and Science, Youth and Sport of Regional State 
Administrations and subordinate structures of the lower administrative level, as well as profile structural subdivisions of local self-government bodies) according to the formulation of proposals for improvement standardized approaches to the educational process, which will increase the opportunities for more effective use and development of the educational potential of the regions with the binding to other resource opportunities" [11, p. 112].

It is extremely important in preparing a future teacher, because there are peculiarities in the work, depending on where in Ukraine there is a school: in the city or in the countryside; in Hutsulshchyna, Bukovyna or Pokuttia, etc. As a result, the regional component of the content of school education is inseparable from the holistic formation of the child's personality, its socio-cultural development. Accordingly, pedagogical universities (faculties) adapt their curriculum and teacher training programs.

Obviously, that in the preparation of a teacher a technological component should be the determining factor, because the XXI century is the time of rapid development of information and communication technologies, formation of a "network" human. T. Piątek, along with such important competences of a modern pedagogue, such as: praxeological, communication, creative, moral, etc., distinguishes informational [9, p. 39]. After all, the future teacher must improve his personality through self-education, to show creativity in professional activities.

According to the educational and organizational norms, then the obligatory primary regulation (standardization) is subject not so much to the organizational methods as the methodological norms of pedagogy at the higher school. Here also belong such important foundations of education as introducing elements of creative learning technology instead of the existing reproductive system in our country, as well as modular rating organization of training. Not the last place takes the problem of unifying the requirements of a modern high school teacher [13].

\subsection{Teacher Training to Create a Socio-Cultural Educational Environment For PRIMARY SCHOOL}

The implementation of the Concept of the New Ukrainian School implies the formation of a "modern educational environment, which will provide the necessary conditions, means and technologies for teaching students, educators, parents ..." [8, p. 7]. This environment should contribute primarily to the development of creativity, initiative and autonomy of students in learning the objects and phenomena of the world, to prepare them for independent life, focusing on the needs of each student. And it means that the creation of the educational environment should be based on the principle of human (child-) centralism, based on spiritual and moral values (V. Kremin). In the article 6 of the Law of Ukraine "On Education" (2017) is not accidental human-centralism defined among the principles of state policy in the sphere of education and principles of educational activity [6].

At the same time, in modern education "the relationship between the acquired knowledge and the creative development of the individual is inadequate .., it often happens that the development and selfdevelopment of the child, its personal and self-sufficient formation" [3, p. 7]. Thus, the problem of the developmental potential of the educational environment of the New School is urgent here.

The formation of all components of the educational environment (informational, cultural, educational, spatial and subject, psychological, etc.) in the New Ukrainian School is an extremely important task of innovative teaching. Thus, the modern school should not just "keep pace with life", but also reflect the forward-looking orientation of education. Professional educators should focus their actions on the fact that we are forming a "globalist" person and, at the same time, a patriot of Ukraine.

We are impressed by certain O. Budnyk pedagogical principles of effective formation of the sociocultural environment of a pedagogical educational institution - natural correspondence (concentrator "I am nature"), cultural correspondence (concentrator "I am culture"), humanization (concentrator "I am a human being"), nationality ("I am Ukrainian"), polyethnic (concentrator "I am a representative of the ethnographic group" (Podolyanin, Hutsul, Boiko, Polyschuk, etc.), multiculturalism (concentrator "I am a citizen"), tolerance (concentrator "I am a representative of the world community"), and others. [2]. 
For the modern university, it is extremely important that the principle of cultural correspondence in education is not limited to the trivial transfer of ready-made knowledge of socio-culture, but involves the formation of national feelings of students, ethnic identity, creative thinking development, multicultural competence and mobility.

Future teacher's readiness for professional activity in the contemporary socio-cultural environment is considered to be the criteria for appropriate socio-cultural competence, which manifests itself in the ability to apply professional knowledge and skills in the external environment and value attitude to educational activities. For example, in the system of vocational and pedagogical training, an important place belongs to the socio-cultural education of students, which is understood as "the process and result of purposeful influence on the person with the aim of mastering it by the knowledge of universal and national culture, social values and positively significant qualities. Accordingly, upbringing helps the student comprehend his belonging to a society, an appropriate tradition and culture, to socialize and personally realize" [1].

Effectiveness of the professional training of teachers of the New Ukrainian School for socio-cultural upbringing of students is determined by a number of psychological and pedagogical conditions: the socio-cultural orientation of the educational environment of the educational institution; implementation of interpersonal relations; motivational and value attitude to pedagogical activity in the ethnointellectual space and taking into account the principles of humanization, ethnization, cultural conformity, natural correspondence, accessibility, emotionality, democratization, harmony of familyschool education, etc. The preparation of future teachers for socio-cultural education of junior pupils involves, first of all, determining the level of socio-cultural competence of students regarding professional activity in a specific ethno-environment and analysis of factors that have a significant impact on its formation in higher pedagogical educational establishments.

An important aspect of teacher training is social and cultural mobility as a complex process and the result of intellectual and cultural knowledge of the values of the relevant social environment, patterns of behavior, educational traditions, especially within the framework of vocational and pedagogical preparation or activity, etc.

Actually, the professional training of the teacher is aimed at forming socio-cultural selfconsciousness, determining the place and status in the socio-cultural environment. The result of training a specialist at a pedagogical institute (university) in socio-cultural aspect is the student's assimilation of the integrity of socio-cultural experience of mankind in reflecting on a personal level. Socio-cultural context in this aspect is a meaningful characteristic of vocational and pedagogical education, the process of mastering the corresponding competencies - in accordance with procedural characteristics, and the personal moral and spiritual values of the future specialist - the productive component.

Thus, socio-cultural mobility is closely connected with the process of professionalization of the future teacher of primary school. "Professionalization is defined as a holistic uninterrupted process of changing a person in a professional, beginning with the moment of the choice of a profession, it lasts throughout the professional life of a person and ends when a person ceases his professional activity" [10, p. 247-248]. In the pedagogical process of the university considerable attention should be paid to the development of professionally significant qualities of students, taking into account their transition to the next level of professionalism.

\section{CONCLUSiOnS}

The socio-cultural dimension of the professional activity of the future teacher of primary school is manifested through the social and value characteristics of the personality as a bearer of universal human, national and personal professional and pedagogical culture; readiness on the principles of subject-subjective interaction to form a holistic personality of a junior schooler, capable of selfrealization in a society, in a certain socio-cultural environment. Socio-cultural mobility of the teacher, which is closely connected with the process of its professionalization, implies its active activity in 
adapting and accepting the values of a socio-cultural environment. At the same time, in the New Ukrainian School, the prominent place belongs to the purposeful socio-cultural education of children, which should be prepared by a modern educator. After all, dynamic social processes, the phenomenon of globalization, the need for the formation of a civil society, the cultivation of national identity and identity predetermine the public's interest in the issues outlined, and, consequently, in teaching.

A major task is to prepare the teacher for the design of the modern educational environment of the New Ukrainian Primary School, which would contribute to the development of creativity, initiative, autonomy, creative abilities and interests of students. For this purpose, it is necessary to foresee appropriate standards for the training of the primary education specialist on the direction of the higher schools in the specified direction for the creation of an innovative educational space - the systematic process of introducing information and communication technologies in the teaching of various pedagogical disciplines, development of appropriate electronic resources, creation of research laboratories, online courses etc. Considerable attention should be paid to the design of the educational environment of the school, which is aimed at stimulation the educational and cognitive interests of students, their involvement in learning through research, increasing the motivation of studying, etc.

We consider preparation of future specialists to master innovative methods and teaching tools, develop creativity and ability to work in the team should be the matters for further scientific researches.

\section{REFERENCES}

[1] Budnyk O. Education of pupil's personality in sociocultural environment of modern school. Scientific Bulletin of Chetm, 1 (2016), 133-142.

[2] Budnyk O. The educational environment of a pedagogical educational institution: theoretical and methodological aspect. Pedagogy and Psychology of professional education, 5 (2012), 175-184. (in Ukrainian)

[3] Kremen V.H. Education, personality and social progress. Education for the present time, 1 (2015), 6-12. (in Ukrainian)

[4] Kremen V.H. Philosophy of human-centeredness in the educational space. Company "Knowledge" Ukraine, Kyiv, 2011. (in Ukrainian)

[5] Kyselova O.I., Yankova O.B. Content and tasks of standardization of higher education. Science and Education, 6 (2013), 90-95. (in Ukrainian)

[6] Law of Ukraine "On Education": adopted on 05.09.2017. Available at: http://osvita.ua/ legislation/law/2231/. (in Ukrainian)

[7] Markocki Z. Teacher - educator towards the new educational reality of societies. In: Prewka C. KU Good School. Teachers. Education technologies, 2. TWP Higher School of Humanities in Szczecin, Institute for Sustainable Technologies. PIB, Radom, 2009. (in Polish)

[8] New Ukrainian School. Conceptual principles of reforming secondary school. Available at: https://www.kmu.gov.ua/storage/app/media/reforms/ukrainska-shkola-compressed.pdf. (in Ukrainian)

[9] Piatek T. The cultural aspect of teacher education in the information society. In: Pedagogical education and science in the conditions of the classical university: traditions, problems, perspectives, 1. Ivan Franko National University of Lviv, Lviv, 2013. (in Polish)

[10] Piletska L.S. Mobility is a necessary condition for the professional development of the individual. Psychology and Personality, 2 (1) (2015), 243-257. (in Ukrainian)

[11] Shevchuk A.V. Standardization of education as an important condition for the development of regional educational systems. Regional economy, 1 (2013), 107-113. (in Ukrainian)

[12] Yevtukh M., Pelekh Yu., Matviychuk A. Post-non-classical pedagogy: philosophical and methodological conception of the scientific concept. Education for the present time, 1 (2015), 104-117. (in Ukrainian)

[13] Zinkovskyy Yu.F. Standardization in education. Journal of Kremenchuk Mykhailo Ostrohradskyi National University, 5 (64) (2010), 204-207. (in Ukrainian) 
Address: Anna Voitovych, Ivan Franko National University of Lviv, 1, Universytetska Str., Lviv, 79000, Ukraine.

E-mail: an.voit@ukr.net.

Received: 01.12.2017; revised: 22.03.2018.

Войтович Анна. Професійна підготовка вчителя Нової української початкової школи. Журнал Прикарпатського університету імені Василя Стефаника, 5 (1) (2018), 95-101.

У статті висвітлено актуальні проблеми професійної підготовки майбутнього вчителя початкової школи в умовах реформування системи освіти в України. Значну увагу приділено соціокультурному складнику у педагогічному процесі вищого навчального закладу, а також питанням стандартизації освіти. Автор акцентує на тому, що динамічні суспільні процеси, явище глобалізації, потреби формування громадянського суспільства, плекання національної самосвідомості та ідентичності зумовлюють зацікавлення громадськості до окреслених питань, передусім вчительства. Обгрунтовано теоретичні аспекти підготовки вчителя до створення соціокудьтурного освітнього середовища початкової школи, реалізації можливостей соціокультурної мобільності та ін. Доведено, що соціокультурна мобільність учителя, яка тісно пов'язана 3 процесом професіоналізації, передбачає його активну діядьність щодо адаптації й прийняття цінностей того чи іншого соціальнокудьтурного середовища. Наголошено на потребі підготовки майбутніх фахівців початкової освіти до цілеспрямованого соціокультурного виховання дітей.

Ключові слова: підготовка вчителя, стандартизація освіти, соціокультурна мобільність, Нова українська школа, вищий навчальний заклад. 